\title{
Conformação da produção de cacau no Sul da Bahia com a legislação florestal brasileira
}

\author{
Synthya Torquato dos Reis ${ }^{1}$ (D), Naisy Silva Soares ${ }^{2}$ (D), Lyvia Julienne Sousa Rego ${ }^{3}$ \\ ${ }^{1}$ Ministério Público do Estado da Bahia. Sede Principal: 5a Avenida, n 750, do CAB, Salvador, BA - Brasil, 41745004. \\ ${ }^{2}$ Departamento de Ciências Econômicas, Universidade Estadual de Santa Cruz, Campus Soane Nazaré de Andrade, \\ Rod. Jorge Amado, Km 16 - Salobrinho, Ilhéus - BA, 45662-900. \\ ${ }^{3}$ Centro de Formação em Ciências e Tecnologias Agroflorestais da Universidade Federal do Sul da Bahia, Rodovia \\ Ilhéus/Itabuna, Km 22, Ilhéus-BA, Brasil, 45604-811 \\ * Autora para correspondência: naisysilva@yahoo.com.br
}

Recebido em 27 de maio de 2020.

Aceito em 09 de dezembro de 2020.

Publicado em 31 de dezembro de 2020.

Resumo - A implantação de políticas públicas para o cacau no país, desde a década de 30 do século $\mathrm{XX}$, determinou a cadência da produção do fruto na região Sul baiana. O novo Código Florestal, também interfere nessa dinâmica, pois visa proteção, orientação e disciplina das atividades produtivas Objetivou-se analisar a conformação da produção de cacau no Sul da Bahia com a legislação florestal brasileira. Foram analisados o perfil dos produtores e das propriedades de cacau do Sul da Bahia, a percepção dos produtores sobre a legislação e a conformação da propriedade rural com a legislação florestal. Os dados são primários e coletados por meio de questionário aplicado produtores de cacau do Sul da Bahia. Verificou-se que a maioria das propriedades analisadas estão em situação irregular com relação à legislação florestal.

Palavras-chave: código florestal; produção agrícola; desenvolvimento sustentável.

\section{Compliance of cocoa production in southern Bahia with Brazilian forest legislation}

\begin{abstract}
The implementation of public policies for cocoa in the country, since the 1930s of the 20th century, determined the pace of fruit production in the southern region of Bahia. The new Forest Code also interferes in this dynamic, as it aims to protect, guide and discipline production activities. The objective was to analyze the conformity of cocoa production in Southern Bahia with the Brazilian forest legislation. The profile of cocoa producers and properties in the south of Bahia, the perception of the legislation by producers and compliance of the rural property with the forest legislation were analyzed. The data are primary and were collected using a questionnaire applied to cocoa producers in the south of Bahia. It was found that most of the properties analyzed are in an irregular situation regarding forest legislation.
\end{abstract}

Keywords: forest code; agricultural production; sustainable development. 


\section{Conformación de la producción de cacao en el Sur de Bahía con la legislación forestal brasileña}

Resumen - La implementación de políticas públicas para el cacao en el país, desde la década de 30 del siglo XX, determinó el ritmo de producción del fruto en la región sur de Bahía. El nuevo Código Forestal también interfiere en esta dinámica, ya que busca proteger, orientar y disciplinar las actividades productivas, con el objetivo de analizar la conformación de la producción de cacao en el sur de Bahía con la legislación forestal brasileña. Se analizó el perfil de los productores y fincas de cacao del sur de Bahía, la percepción de los productores sobre la legislación y la conformación de la propiedad rural con la legislación forestal. Los datos son primarios y se recopilan mediante un cuestionario que se aplica a los productores de cacao en el sur de Bahía. Se encontró que la mayoría de las fincas analizados se encuentran en situación irregular con respecto a la legislación forestal.

Palabras clave: código forestal; producción agrícola; desarrollo sostenible.

\section{Introdução}

Ao longo dos anos, com o aumento do consumo de chocolate, o cacau adquiriu importância econômica e sementes do fruto foram se espalhando gradualmente pelo mundo.

Em 1670, ainda na era colonial, tem-se os primeiros registros sobre o plantio sistemático de cacau no Brasil, na região amazônica. Mas, foi no século XVIII, que o cacau chegou ao Sul da Bahia (Chambouleuron, 2014).

De acordo com Rocha (2008) a partir das primeiras décadas do século XX o cacau se consolidou como o principal produto agrícola da Bahia. Contudo, a partir de 1988, com a infestação da vassoura de bruxa, a queda de produção e os preços rebaixados do cacau sufocaram o produtor já fragilizado, chegando a se considerar que a cacauicultura baiana passava pela pior crise econômica em toda a sua história. Foi um momento de abandono das roças, o que veio a absorver decisivamente a CEPLAC, que para saná-la viabilizou novos programas de contenção da crise (Almeida, 2012).

A partir de 1989, onde por reflexo da contaminação, engendra-se uma profunda crise da lavoura, comprometendo os preços do cacau, empobrecendo a região. Isso motivou o governo baiano a inserir no seu programa agrícola uma política que amparasse o cacau, o Programa Baiano de Tecnologia Apropriada (PBTA), para incentivar a produção de diversos arranjos produtivos do Estado (Almeida, 2012).

Contudo, a promulgação do Código Florestal Brasileiro, em 1965, estabeleceu restrições para o uso do solo nas propriedades rurais, das áreas de reserva legal e de preservação permanente. Tais restrições permaneceram, durante anos, com limitada aplicação, tendo como resultado a progressiva degradação do meio ambiente e distanciamento dos produtores rurais em relação às políticas públicas (Silva, 2012). O novo Código Florestal, promulgado 2012 através da Lei n. 12.651, revogou o Código de 1965, tornando-o sem efeito, ainda que alguns institutos sejam originários do Código de 1965, a até mesmo do de 1934.

Mais especificamente, o Código Florestal cuida da proteção à floresta e demais formas de vegetação, não desconsiderando que a floresta é uma espécie de vegetação, mas sim reforçando a abrangência da lei para proteção do conjunto da vegetação.

Qualquer transgressão às normas ambientais, seja por uma conduta comissiva (por uma ação), seja por uma conduta omissiva, pode ser caracterizada como uso irregular do solo. De acordo com 
o art. 225, $₫ 3^{\circ}$ da CFRB tais condutas, se consideradas danosas ao meio ambiente "sujeitarão os infratores, pessoas físicas ou jurídicas, a sanções penais e administrativas, independentemente da obrigação de reparar os danos causados" (Brasil, 1988; Sirvinskas, 2018).

A preocupação com a proteção ao meio ambiente provocou mudanças institucionais, transformando a estrutura legal, a exemplo da exigência de áreas de preservação. No entanto, como observou Klein (2015), se de alguma forma a "preservação ambiental possibilita mudar os rumos do desenvolvimento em benefício das gerações futuras, por outro os mecanismos criados para garantir tal objetivo podem impactar diretamente na atividade agrícola”.

Em pesquisa realizada por Tourinho (2005) foi constatado inúmeros obstáculos que impediam que pequenos produtores cumprissem a lei, dentre elas o alto custo de averbação da reserva legal e da burocracia nos processos de licenciamento. O Novo Código Florestal (Brasil, 2012) aponta para um cenário de minimização desses problemas, prevendo institutos que facilitam a regularização das pequenas propriedades. Inclusive um dos principais argumentos utilizados quando da aprovação do novo Código Florestal foi a dificuldade dos agricultores, em especial dos pequenos, para realizar a regularização ambiental (Sirvinskas, 2018). Nesse sentido, essas leis possuem caráter de proteção, orientação e disciplina das atividades produtivas.

Os agricultores viram-se obrigados a se adequar às normas e aos regulamentos vigentes, o que gerou insatisfação por parte desse segmento da sociedade. Isto porque as cobranças dos atributos legais ambientais nas propriedades rurais começaram a incidir no Brasil com mais rigor a partir de 2008, quando o Decreto n. 6.514, que dispõe sobre as infrações e sanções administrativas ao meio ambiente, estabeleceu o processo administrativo federal para apuração destas infrações (Polízio Júnior, 2016).

Percebe-se então que exigências relacionadas com as áreas de preservação permanente e reserva legal, com a preservação da vegetação nativa, como essencial para o desenvolvimento sustentável. Com isso, áreas que antes eram utilizadas para a produção de forma inadequada passam a ser reconhecidas como áreas que devem ser preservadas, segundo o Código Florestal Brasileiro (Polízio Júnior, 2016).

Nesse sentido, Viana (2004) afirma que há um conflito presente na proteção do meio ambiente, no crescimento econômico do país e na renda daqueles que se dedicam à exploração da terra, principalmente os produtores.

Nesse contexto, busca-se testar as seguintes hipóteses: A legislação florestal está sendo cumprida pelos produtores de cacau na microrregião Ilhéus - Itabuna; e os produtores conhecem e concordam com a legislação florestal brasileira.

Trabalhos nesse sentido são importantes para elaboração de políticas públicas para o desenvolvimento da cacauicultura na região e no país.

Assim, o presente trabalho tem como objetivo geral analisar a conformação da produção de cacau no Sul da Bahia com a legislação florestal brasileira. Especificamente, analisou-se o perfil dos produtores e das propriedades de cacau do Sul da Bahia, a percepção dos produtores sobre a legislação e o cumprimento da legislação florestal nas propriedade rurais da região em estudo. 


\section{Material e método}

O estudo foi realizado na microrregião Ilhéus - Itabuna, Bahia, no ano de 2019, a partir da coleta de dados primários obtidos por meio de aplicação de questionário a uma amostra de produtores de cacau no Sul da Bahia que aceitarem fazer parte desta pesquisa.

Ressalta-se que a pesquisa foi a provado pelo Comitê de Ética em Pesquisa da Universidade Estadual de Santa Cruz.

A microrregião de Ilhéus-Itabuna, denominada região cacaueira é uma das microrregiões da Bahia pertencente à mesorregião Sul Baiana. Sua população foi estimada no ano de 2007 em 1.081.347 habitantes e está dividida em 41 municípios. Possui uma área total de $21.308,944 \mathrm{~km}^{2}$. É a microrregião com mais cidades em toda Bahia (IBGE, 2018).

Contudo, foram analisadas propriedades e produtores dos municípios de Ilhéus, Itacaré, Maraú, Una, Itajuípe, Uruçuca, Buerarema, Canavieiras e Itabuna, pois esses municípios foram representativos em termos de produção, pois representaram cerca de $70 \%$ da produção da região, em 2019 (Figura 1). Além disso, localizam-se próximos um do outro, facilitando a coleta de dados.

\section{Municípios integrantes da amostra a ser pesquisada}
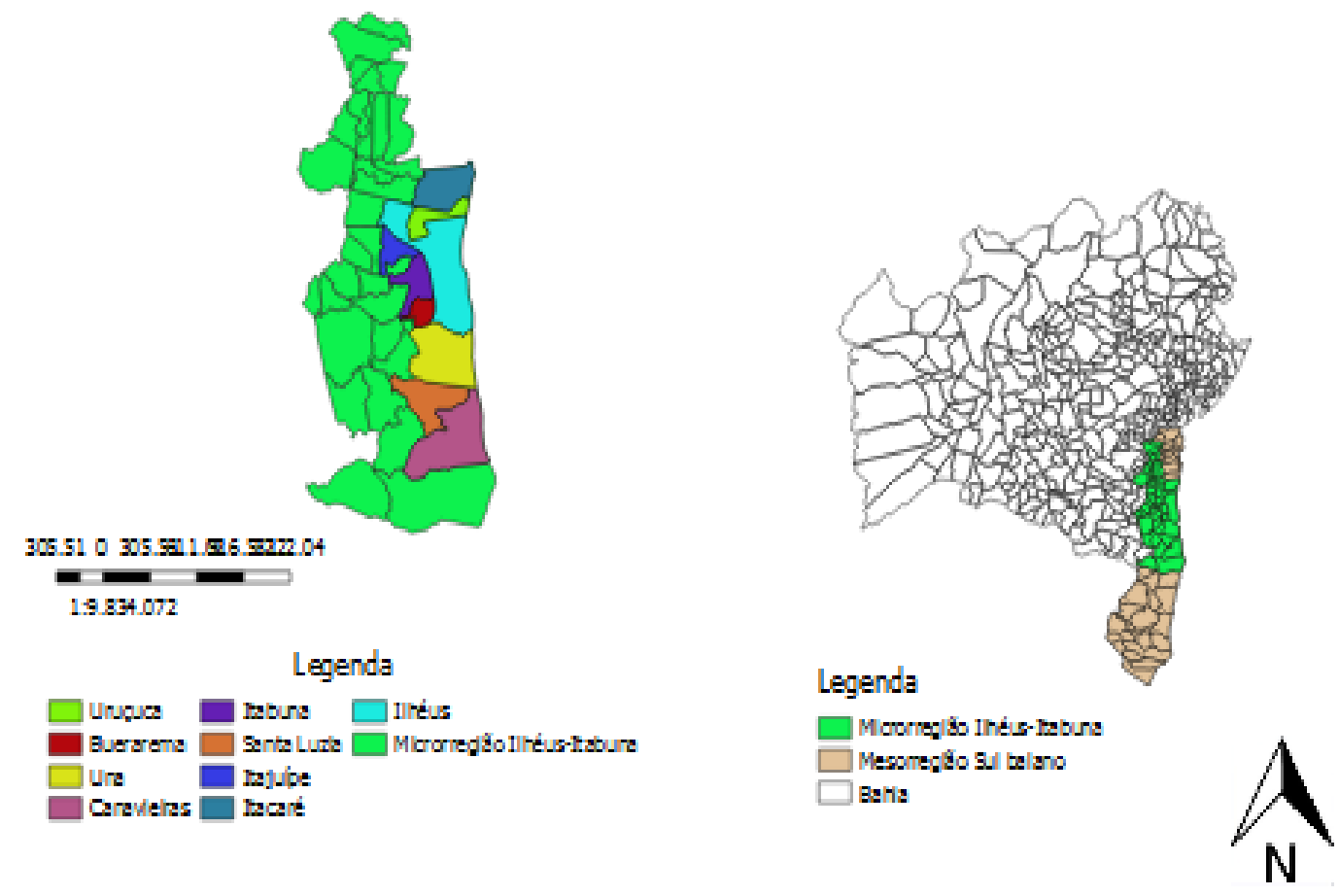

Fonte: IBGE, 2018. Elaboração da autora.

Assim, foi calculada uma amostra probabilística, conforme Equação 1, considerando que a aplicação dos questionários respeita ao método estatístico de população finita com amostragem aleatória simples com um nível de confiança de 90\% e erro amostral de 10\% (GIL, 2002). 


$$
n=\frac{\delta^{2} p \cdot q \cdot N}{e^{2}(N-1)+\delta^{2} \cdot p \cdot q} .
$$

em que: $\mathrm{n}$ = tamanho da amostra; = nível de confiança; $\mathrm{p}$ = probabilidade do fenômeno ocorrer; $\mathrm{q}$ = probabilidade complementar; $\mathrm{N}$ = tamanho da população; e e = erro máximo.

Assim, em cada município da amostra foram analisadas o seguinte número de propriedades: Ilhéus (31), Itacaré (14), Maraú (12), Una (11), Itajuípe (10), Uruçuca (8), Buerarema (6), Canavieiras (6) e Itabuna (4).

A análise sobre o perfil dos produtores e das propriedades envolveu questões relacionadas com escolaridade/formação do produtor ou do proprietário, idade, número de dependentes e de pessoas que vivem na propriedade, função do produtor na propriedade, anos que trabalha na propriedade e com o cacau e outras culturas, renda média mensal com a atividade cacaueira e demais atividades, parcela da propriedade que é usada para o cultivo do cacau e outras atividades, e localização da propriedade.

A percepção dos produtores sobre a legislação florestal foi analisada por meio de questões sobre o conhecimento do produtor sobre a legislação vigente e sua opinião sobre ela, fiscalização da propriedade, licenciamento e cadastro ambiental.

$\mathrm{Na}$ análise da conformação da propriedade rural com a legislação florestal constam questões que envolvem as áreas de reserva legal e de preservação permanente, bem como o código florestal brasileiro, no sentido de verificar o cumprimento da lei pelo produtor.

\section{Resultados e discussão}

\section{Perfil dos produtores e das propriedades de cacau do Sul da Bahia}

Verificou-se que a maior parte dos produtores entrevistados não completou o ensino fundamental. No total geral, $63 \%$ dos produtores não possuem escolaridade ou frequentaram a escola por no máximo 4 anos. O município de Una se destaca por apresentar $82 \%$ dos pequenos produtores com faixa de escolaridade de até quatro anos. Já o município vizinho, Canavieiras, se destaca pelo fator oposto. Isto porque $50 \%$ dos pequenos produtores frequentaram a escola de 5 a 8 anos, estando próximos da conclusão do ensino fundamental. Por outro lado, dos nove municípios, apenas Ilhéus, Itajuípe, Uruçuca e Buerarema possuem produtores com educação formal por mais de 12 anos (Quadro 1). 
Quadro 1. Caracterização dos produtores e das propriedades de cacau do Sul da Bahia, por município, em 2019, em \%

\begin{tabular}{|c|c|c|c|c|c|c|c|c|c|c|c|}
\hline Item & Caracterização & & & & & & Municípi & & & & \\
\hline- & - & Ilhéus & Itacaré & Maraú & Una & Itajuípe & Uruçuca & Buerarema & Canavieiras & Itabuna & Geral \\
\hline \multirow{4}{*}{ Escolaridade (anos) } & Até 4 & 55 & 71 & 84 & 82 & 60 & 63 & 50 & 33 & 75 & 63 \\
\hline & De 5 a 8 & 29 & 29 & 8 & 0 & 20 & 25 & 17 & 50 & 0 & 22 \\
\hline & De 9 a 17 & 3 & 0 & 8 & 18 & 10 & 0 & 17 & 17 & 25 & 8 \\
\hline & Mais de 12 & 13 & 0 & 0 & 0 & 10 & 12 & 16 & 0 & 0 & 7 \\
\hline \multirow{3}{*}{ Idade (anos) } & Até 40 & 10 & 21 & 25 & 0 & 20 & 0 & 17 & 33 & 0 & 14 \\
\hline & 41 a 60 & 32 & 65 & 50 & 36 & 70 & 37 & 83 & 0 & 100 & 47 \\
\hline & Mais de 61 & 58 & 14 & 25 & 64 & 10 & 63 & 0 & 67 & 0 & 39 \\
\hline \multirow{5}{*}{ Tempo de trabalho com o cacau (anos) } & Até 10 & 3 & 44 & 0 & 18 & 20 & 0 & 33 & 16 & 25 & 15 \\
\hline & De 11 a 20 & 35 & 14 & 25 & 18 & 20 & 0 & 17 & 17 & 25 & 22 \\
\hline & De 21 a 30 & 3 & 7 & 16 & 9 & 20 & 0 & 50 & 17 & 25 & 12 \\
\hline & De 31 a 40 & 16 & 14 & 17 & 9 & 20 & 37 & 0 & 0 & 25 & 16 \\
\hline & Mais de 41 & 43 & 21 & 42 & 46 & 20 & 63 & 0 & 50 & 0 & 35 \\
\hline \multirow{3}{*}{ Tempo de trabalho na propriedade (anos) } & Até 5 & 9 & 28 & 0 & 18 & 20 & 63 & 33 & 33 & 25 & 20 \\
\hline & De 6 a 15 & 68 & 36 & 17 & 18 & 50 & 0 & 17 & 33 & 50 & 40 \\
\hline & Mais de 16 & 23 & 36 & 83 & 64 & 30 & 37 & 50 & 34 & 25 & 40 \\
\hline Parcela da propriedade com cacau $(\mathrm{Ha})$ & - & 6 & 4 & 6 & 5 & 19 & 21 & 10 & 2 & 9 & 9 \\
\hline \multirow{5}{*}{ Forma de aquisição da propriedade } & Adquirida & 23 & 29 & 25 & 64 & 70 & 51 & 50 & 67 & 25 & 40 \\
\hline & Herdada & 0 & 14 & 75 & 18 & 20 & 12 & 50 & 33 & 75 & 23 \\
\hline & Contrato de parceria agrícola & 0 & 7 & 0 & 0 & 0 & 12 & 0 & 0 & 0 & 2 \\
\hline & Ocupação & 77 & 43 & 0 & 18 & 10 & 25 & 0 & 0 & 0 & 34 \\
\hline & Outros & 0 & 7 & 0 & 0 & 0 & 0 & 0 & 0 & 0 & 1 \\
\hline
\end{tabular}


Observa-se que a maior parte dos produtores possui mais de 41 anos de idade (juntos somam $83 \%$ ). No total geral, $47 \%$ possuem de 41 a 60 anos, e 39\% mais de 61 anos. Apenas 14\% têm menos de 40 anos de idade. O município de Canavieiras se destaca com a maior quantidade de jovens produtores (33\%). Una, é o município que apresenta o maior número de produtores com mais de 61 anos (64\%) (Quadro 1). O mesmo destaque de faixa etária e baixa escolaridade foi encontrado em fruticultores de manga, maracujá, banana e pinha na Bahia (Oliveira et al. 2016; Leite et al. 2016).

Segundo IBGE (2020), o perfil do produtor rural brasileiro é de baixa escolaridade. De acordo com a pesquisa do instituto, as regiões Norte e Nordeste concentram os maiores percentuais de produtores analfabetos ou sem nenhum ano de estudo, enquanto Centro-Oeste e Sudeste têm os maiores percentuais de produtores com técnico agrícola ou Ensino Médio completo. A maior concentração de centros de pesquisa e ensino nessas regiões ajuda a explicar a distorção.

Verificou-se, também, que a maioria dos produtores trabalha a mais de 40 anos com o cacau e a mais de 15 anos na propriedade, indicando experiência do produtor com a cultura, bem como fonte de renda e emprego por vários anos com o cacau (Quadro 1).

Questionados sobre a forma de aquisição da propriedade, $40 \%$ afirmaram ter adquirido/ comprado; $23 \%$ herdado; $2 \%$ têm posse por contrato de parceria agrícola/meação e $34 \%$ por ocupação. Em Ilhéus e Itacaré a maior parte das roças são possuídas por ocupação, $77 \%$ e $43 \%$ respectivamente. Em Maraú, Buerarema e Itabuna se destaca a obtenção da propriedade por processo sucessório, onde $75 \%, 50 \%$ e $75 \%$, respectivamente, foram adquiridas através de herança. Una, Itajuípe, Uruçuca, Buerarema e Canavieiras possuem, respectivamente, 64\%, 70\%, 51\%, 50\% e 67\% de propriedades compradas (Quadro 1).

Observou-se que $40 \%$ dos produtores cultivam apenas cacau em suas roças, tendo apenas o cacau como fonte de renda na propriedade. Assim, verificou-se que a maior parte das propriedades analisadas, $60 \%$, cultivam cacau e outras culturas, sendo que as culturas que mais se destacaram em Ilhéus foram banana e mandioca; em Itacaré, banana, mandioca, açaí e coco; em Maraú, mandioca; em Una, coco, banana e seringa; em Itajuípe, nota-se a forte presença do gado de corte e de leite e mandioca; em Uruçuca, destacou-se a produção do açaí, banana e mandioca; em Buerarema, mandioca; em Canavieiras, banana e coco; e em Itabuna, hortaliças em geral. Contudo, em média, 9 ha das roças são destinadas ao cultivo do cacau, com ressalva que o selo de Indicação Geográfica (IG) Sul da Bahia contribui para manter o padrão de qualidade do cacau produzido no sul do estado, segundo Sant 'Ana et al, 2020.

No total geral, verificou-se que $29 \%$ das propriedades apresentam até 5 ha; $29 \%$ de 6 ha a 10 ha; $11 \%$ de 11 ha a 15 ha; $7 \%$ de 16 ha a 20 ha; e $24 \%$ mais de 21 ha. Em Ilhéus, $62 \%$ das propriedades possuem entre 6 ha a 10 ha. Em Itacaré, 36\% possuem até 5 ha. Entre as propriedades com menos de 5 ha destacou-se Maraú, que possui $67 \%$ das propriedades com esse tamanho. Em Una, 46\% das propriedades possuem entre 11 ha e 15 ha. Itajuípe, Uruçuca, Buerarema e Itabuna se apresentam fora da média, onde possuem, respectivamente, $40 \%, 50 \%, 66 \%$ e $75 \%$ de suas pequenas propriedades com mais de 21 ha. Em Canavieiras 50\% das propriedades possuem entre 6 ha a 10 ha.

Verificou-se que na maior parte das propriedades destacou-se a mão de obra familiar (52\%). Já $24 \%$ contratam funcionários sob por remuneração variável, que engloba diaristas e empreiteiros, $13 \%$ sob o regime celetista e $11 \%$ por contrato de parceira agrícola/meeiro. Os municípios de Ilhéus, Itacaré, Maraú, Una e Canavieiras seguem a média geral, e possuem mão de obra familiar, respectivamente, em 55\%,72\%,75\%,73\% e 50\% de suas pequenas propriedades. Já Itajuípe 
possui como celetista $50 \%$ de sua mão de obra. Em Uruçuca predomina a remuneração variável (empreiteiros, diaristas, etc) (38\%). Buerarema e Itabuna possuem um equilíbrio entre mão de obra celetista e por parceria agrícola.

Observou-se que a renda média mensal com o cacau representa $63,48 \%$ da renda do produtor com a terra e os outros cultivos representam juntos 36,52\% (Quadro 2). O destaque para o cacau ocorreu em razão do seu cultivo ser uma prática cultural que apoia economicamente a região cacaueira do sul da Bahia, desde meados do século XIX (Segundo et al. 2014), com isso os produtores acabam cultivando mais essa espécie do que outras, que servem como fontes complementares de renda (Sambuichi, 2006).

Quadro 2 - Renda média mensal dos produtores nas propriedades de cacau do Sul da Bahia, em 2019, por município, em reais

\begin{tabular}{|c|c|c|}
\hline Municípios & Renda média com o cacau & Renda média com outras culturas \\
\hline Ilhéus & 880 & 404 \\
\hline Itacaré & 332 & 290 \\
\hline Maraú & 793 & 150 \\
\hline Una & 757 & 727 \\
\hline Itajuípe & 1.626 & 1.960 \\
\hline Uruçuca & 3.444 & 1.039 \\
\hline Buerarema & 2.362 & 0 \\
\hline Canavieiras & 413 & 0 \\
\hline Itabuna & 1.017 & 1.875 \\
\hline Média & 1.292 & 644,5 \\
\hline
\end{tabular}

Os produtores com maior renda obtida com a cultura do cacau estão localizados nos municípios de Uruçuca, Buerarema e Itajuípe. Estes possuem renda com o cacau superior à media (Quadro 2). A facilidade do escoamento da produção pelas rodovias nesses municípios, que marcou o desenvolvimento da cultura cacaueira, citado por Aguiar e Pires (2018), pode favorecer o aumento da renda.

No caso do cultivo de outras culturas, os município de Itabuna, Uruçuca, Itajuípe e Una apresentaram renda superior à media em relação ao cultivo do cacau (Quadro 2).

Verificou-se que apenas os municípios de Itajuípe e Una apresentaram renda maior com o cultivo de outras culturas em relação ao cacau (Quadro 2).

\section{Percepção dos produtores sobre a legislação florestal}

O Quadro 3 mostra que 49\% dos produtores entrevistados afirmaram conhecer parcialmente a legislação florestal brasileira, ao passo que $48 \%$ afirmaram conhecer da legislação sem qualquer ressalva. No total geral apenas $3 \%$ disseram desconhecê-la, e foram nos municípios de Ilhéus e Una 
tais intercorrências (6\% e 9\%, respectivamente, afirmaram não conhecer). Os municípios onde os produtores mais conhecem a legislação florestal foram Uruçuca, com $88 \%$ e Itabuna com $100 \%$.

No tocante a concordância sobre a legislação florestal brasileira, $72 \%$ dos produtores afirmaram concordar sem ressalvas, $22 \%$ concordam parcialmente e 6\% discordam. Apenas nos municípios de Itacaré, Uruçuca, Buerarema e Itabuna nenhum entrevistado afirmou discordar da legislação florestal (Quadro 3).

Quadro 3 - Percepção dos produtores sobre a legislação florestal brasileira no Sul da Bahia e cumprimento da legislação, em 2019, por município, em \%

\begin{tabular}{|c|c|c|c|c|c|c|c|c|c|c|c|c|c|c|c|c|c|c|c|c|c|c|c|c|c|c|c|c|c|c|}
\hline \multirow[t]{2}{*}{ Itens } & \multicolumn{3}{|c|}{ Ilhéus } & \multicolumn{3}{|c|}{ Itacaré } & \multicolumn{3}{|c|}{ Maraú } & \multicolumn{3}{|c|}{ Una } & \multicolumn{3}{|c|}{ Itajuípe } & \multicolumn{3}{|c|}{ Uruçuca } & \multicolumn{3}{|c|}{ Buerarema } & \multicolumn{3}{|c|}{ Canavieiras } & \multicolumn{3}{|c|}{ Itabuna } & \multicolumn{3}{|c|}{ Geral } \\
\hline & $\mathrm{S}$ & $\mathrm{N}$ & $\mathrm{P}$ & S & $\mathrm{N}$ & $\mathrm{P}$ & S & $\mathrm{N}$ & $\mathrm{P}$ & S & $\mathrm{N}$ & $\mathrm{P}$ & S & $\mathrm{N}$ & $\mathrm{P}$ & S & $\mathrm{N}$ & $\mathrm{P}$ & S & $\mathrm{N}$ & $\mathrm{P}$ & S & $\mathrm{N}$ & $\mathrm{P}$ & S & $\mathrm{N}$ & $\mathrm{P}$ & $S$ & $\mathrm{~N}$ & $\mathrm{P}$ \\
\hline $\begin{array}{l}\text { Conhecimento } \\
\text { sobre a legislação }\end{array}$ & 46 & 6 & 48 & 43 & 0 & 57 & 42 & 0 & 58 & 55 & 9 & 36 & 50 & 0 & 50 & 88 & 0 & 12 & 33 & 0 & 67 & 0 & 0 & 100 & 100 & 0 & 0 & 48 & 3 & 49 \\
\hline $\begin{array}{l}\text { Concordância com } \\
\text { a Legislação }\end{array}$ & 81 & 6 & 13 & 43 & 0 & 57 & 84 & 8 & 8 & 82 & 9 & 9 & 90 & 10 & 0 & 25 & 0 & 75 & 83 & 0 & 17 & 66 & 17 & 17 & 100 & 0 & 0 & 72 & 6 & 22 \\
\hline $\begin{array}{l}\text { Fiscalização da } \\
\text { propriedade pelo } \\
\text { órgão ambiental } \\
\text { periodicamente }\end{array}$ & 48 & 33 & 19 & 21 & 79 & 0 & 8 & 92 & 0 & 27 & 73 & 0 & 20 & 80 & 0 & 25 & 75 & 0 & 17 & 83 & 0 & 0 & 100 & 0 & 0 & 100 & 0 & 26 & 68 & 6 \\
\hline $\begin{array}{l}\text { Propriedade de } \\
\text { acordo com os } \\
\text { planos de bacia } \\
\text { ou de gestão de } \\
\text { recursos hídricos }\end{array}$ & 45 & 52 & 3 & 21 & 79 & 0 & 8 & 92 & 0 & 55 & 45 & 0 & 20 & 80 & 0 & 25 & 75 & 0 & 17 & 83 & 0 & 0 & 100 & 0 & 0 & 100 & 0 & 28 & 71 & 1 \\
\hline $\begin{array}{l}\text { Realização do } \\
\text { licenciamento pelo } \\
\text { órgão ambiental }\end{array}$ & 94 & 6 & 0 & 86 & 14 & 0 & 25 & 75 & 0 & 55 & 45 & 0 & 30 & 70 & 0 & 75 & 25 & 0 & 83 & 17 & 0 & 17 & 83 & 0 & 75 & 25 & 0 & 67 & 33 & 0 \\
\hline $\begin{array}{l}\text { Inscrição } \\
\text { no Cadastro } \\
\text { Ambiental Rural - } \\
\text { CAR ou CEFIR }\end{array}$ & 74 & 23 & 3 & 57 & 36 & 7 & 25 & 75 & 0 & 64 & 36 & 0 & 20 & 80 & 0 & 50 & 50 & 0 & 67 & 33 & 0 & 17 & 83 & 0 & 75 & 25 & 0 & 54 & 44 & 2 \\
\hline
\end{tabular}

Nota: $\mathrm{N}=$ não, $\mathrm{S}=$ Sim, $\mathrm{P}=$ Parcialmente. 
Desta forma, políticas públicas que visem um maior esclarecimento sobre as diretrizes ambientais podem surtir efeitos positivos na região, de modo contribuir para adequação do crescimento econômico ao desenvolvimento sustentável.

Quando perguntados se a propriedade é fiscalizada pelo órgão ambiental periodicamente, $68 \%$ dos entrevistados responderam que não, $26 \%$ que sim, e $6 \%$ parcialmente. O município de Ilhéus foi o que mais recebeu fiscalização em suas propriedades rurais, com $48 \%$ de afirmações. Os produtores de Canavieiras e Itabuna afirmaram nunca receber qualquer tipo de fiscalização de órgãos ambientais (Quadro 3). Isso indica perda de um canal de interlocução proativa com o produtor sobre preservação ambiental e desenvolvimento sustentável.

Sobre os planos de bacia ou planos de gestão de recursos hídricos $71 \%$ asseguraram que a propriedade não está de acordo com diretrizes ali estabelecidas, pois 51,7\% desses produtores não conhecem ou conhecem parcialmente a legislação florestal, ou por não haver um diagnóstico ambiental como identificado por Jardim e Bursztyn (2015) em Minas Gerais, visto que praticamente metade dos cacauicultores aos menos tem o CAR, com as informações ambientais das propriedades.

Nas propriedades sem esses planos estão as que possuem recursos hídricos em situação irregular, bem como aquelas que não possuem recursos hídricos em suas roças (Quadro 3).

A respeito do licenciamento ambiental da propriedade rural no órgão competente, $67 \%$ atestaram que já realizaram. Ilhéus foi o município que possui mais propriedades licenciadas (94\%). Já Canavieiras possui apenas $17 \%$ de suas propriedades licenciadas, valor abaixo da média da microrregião (Quadro 3).

Assim, quanto ao Cadastro Ambiental Rural (CAR)/Cadastro Estadual Florestal de Imóveis Rurais (CEFIR), 54\% das propriedades realizaram e 44\% não realizaram. Isto vale dizer que possivelmente $44 \%$ das propriedades de cacau da microrregião Ilhéus - Itabuna estão inabilitadas a adquirirem qualquer linha de crédito para o fomento da lavoura, estão fora de qualquer estatística estatal na seara da proteção florestal, não podem usufruir das mitigações concedidas pelo código florestal para a regularização de suas propriedades, bem como ser atendido por outros serviços ambientais solicitados ao Estado. Os municípios de Una, Buerarema e Itabuna foram os que apresentaram maior percentual de propriedades com cadastro ambiental (64\%, 67\% e 75\% respectivamente). Maraú, Itajuípe e Canavieiras estão entre os que menos possuem propriedades cadastradas (75\%, 80\% e 83\% respectivamente) (Quadro 3).

Não obstante todos os aparentes conflitos identificados, no total geral, 63\% dos produtores entrevistados consideram o Código Florestal como de alta importância, 32\% de média importância, $3 \%$ de pouca importância e $2 \%$ irrelevante. O município cujo produtor melhor avaliou o Código Florestal foi Una, com $73 \%$ de alta importância. Ilhéus foi o único município onde algum produtor considerou-o irrelevante (representa 6\%) (Quadro 4).

Também foi questionado acerca de institutos específicos do Código Florestal. Para as áreas de preservação permanente foi atribuído $65 \%$ de alta importância, 20\% de média importância, 12\% de baixa importância e 3\% de irrelevância. Desta vez, Ilhéus figurou como o município que melhor avaliou o instituto, com $91 \%$ de alta importância. Maraú foi o que o considerou mais irrelevante (8\%) (Quadro 4). 
Quadro 4 - Grau de importância da legislação e institutos legais que afetam a cacauicultura no Sul da Bahia, em 2019, por município, em \%

\begin{tabular}{|c|c|c|c|c|c|c|c|c|c|c|c|c|c|c|c|c|c|c|c|c|c|c|c|c|c|c|c|c|c|c|c|c|c|c|c|c|c|c|c|c|}
\hline \multirow{2}{*}{$\frac{\text { Itens }}{*}$} & \multicolumn{4}{|c|}{ Ilhéus } & \multicolumn{4}{|c|}{ Itacaré } & \multicolumn{4}{|c|}{ Maraú } & \multicolumn{4}{|c|}{ Una } & \multicolumn{4}{|c|}{ Itajuípe } & \multicolumn{4}{|c|}{ Uruçuca } & \multicolumn{4}{|c|}{ Buerarema } & \multicolumn{4}{|c|}{ Canavieiras } & \multicolumn{4}{|c|}{ Itabuna } & \multicolumn{4}{|c|}{ Geral } \\
\hline & 0 & 1 & 2 & 3 & 0 & 1 & 2 & 3 & 0 & 1 & 2 & 3 & 0 & 1 & 2 & 3 & 0 & 1 & 2 & 3 & 0 & 1 & 2 & 3 & 0 & 1 & 2 & 3 & 0 & 1 & 2 & 3 & 0 & 1 & 2 & 3 & 0 & 1 & 2 & 3 \\
\hline $\begin{array}{l}\text { Código } \\
\text { Florestal }\end{array}$ & 6 & 3 & 19 & 72 & 0 & 0 & 36 & 64 & 0 & 8 & 25 & 67 & 0 & 0 & 27 & 73 & 0 & 10 & 40 & 50 & 0 & 0 & 62 & 38 & 0 & 0 & 33 & 67 & 0 & 0 & 50 & 50 & 0 & 0 & 50 & 50 & 2 & 3 & 32 & 63 \\
\hline $\begin{array}{l}\text { Áreas de } \\
\text { preservação } \\
\text { permanente }\end{array}$ & 3 & 0 & 6 & 91 & 0 & 36 & 21 & 43 & 8 & 17 & 25 & 50 & 0 & 0 & 18 & 82 & 0 & 0 & 40 & 60 & 0 & 50 & 25 & 25 & 0 & 0 & 17 & 83 & 17 & 17 & 17 & 49 & 0 & 0 & 50 & 50 & 3 & 12 & 20 & 65 \\
\hline $\begin{array}{l}\text { Áreas de } \\
\text { reserva legal }\end{array}$ & 0 & 0 & 3 & 97 & 0 & 0 & 36 & 64 & 0 & 17 & 25 & 58 & 0 & 0 & 18 & 82 & 0 & 0 & 30 & 70 & 0 & 0 & 62 & 38 & 0 & 0 & 0 & 100 & 0 & 0 & 50 & 50 & 0 & 0 & 0 & 100 & 0 & 2 & 22 & 76 \\
\hline $\begin{array}{l}\text { Outras } \\
\text { legislações } \\
\text { ambientais }\end{array}$ & 0 & 0 & 10 & 90 & 0 & 0 & 36 & 64 & 8 & 8 & 25 & 59 & 0 & 0 & 36 & 64 & 0 & 10 & 40 & 50 & 0 & 0 & 62 & 38 & 0 & 0 & 33 & 67 & 0 & 17 & 33 & 50 & 0 & 0 & 25 & 75 & 1 & 3 & 28 & 68 \\
\hline
\end{tabular}

Nota: ${ }^{\star}$ Grau de importância $=(0)$ se for irrelevante, $(1)$ para baixa importância, (2) para média importância e (3) para alta importância.

A reserva legal é vista como de alta importância por $76 \%$ dos produtores. Para $22 \%$ dos produtores, é visto de média importância e para $2 \%$, de pouca importância. Ninguém a considerou irrelevante. Mais uma vez a melhor avaliação foi no município de Ilhéus (97\%). Os produtores de Maraú apresentaram a pior avaliação, novamente, com 17\% considerando-o de baixa importância (Quadro 4).

Por fim, foi questionado sobre a legislação ambiental em geral (todas as leis, atos e portarias que regulam tal tema). Para 68\% dos produtores entrevistados esse conjunto legal é de alta importância, $28 \%$ consideram de média importância, 3\% de baixa importância e 1\% irrelevante. As piores avaliações sobre a legislação ambiental foram apontadas pelos produtores de Ilhéus (90\%) e Maraú (8\%) (Quadro 4).

Em síntese, a maioria dos produtores entrevistados consideram a legislação ambiental e suas especificações de grande importância. Reconhecer a importância da legislação pode permitir que produtor brasileiro cumpra as exigências neste aspecto, embora pareça empecilho no curto prazo, uma vez que aqueles que tem área com mata densa tem restrições da legislação ambiental em realizar práticas culturais e eliminar o excesso de sombra para aumentar a produtividade e rentabilidade da lavoura cacaueira (Leite 2018). 


\section{Conformação da propriedade rural com a legislação florestal}

Nesse tópico serão apresentados os resultados referentes à conformação da propriedade rural com a legislação florestal que envolve a análise da distância entre cultivo e áreas de interesse ambiental. Esta por sua vez, engloba a análise das faixas marginais de qualquer curso d'água; lagos, lagoas naturais e Reservatórios d'água artificiais; encostas ou partes destas com declividade superior a $45^{\circ}$; restingas, os manguezais, bordas dos tabuleiros ou chapadas no topo de morros, montes, montanhas e serras; e áreas em altitude superior a $1.800 \mathrm{~m}$ e Veredas.

\section{Distância entre cultivo e áreas de interesse ambiental}

Faixas marginais de qualquer curso d’água

Com base nos resultados obtidos, verificou-se que 37\% das propriedades não possuem curso d'água. Itabuna foi o único município onde todas as propriedades da amostra não o possuíam. $\mathrm{Na}$ categoria de faixa marginal a menos de $29 \mathrm{~m}$ de distância da área de cultivo encontraram-se $47 \%$ das propriedades. De 30 m a 49 m, 1\%. De 50 m a 99 m, 2\%. De 100 m a 199 m, 4\%. De 200 m a 499 m, 2\%. E com mais de $500 \mathrm{~m}$ de distância, 7\%.

Em Ilhéus $67 \%$ das propriedades não possuíam curso d'água. Das $38 \%$ restantes, $29 \%$ tinham a menos $29 \mathrm{~m}$ do local do cultivo; 3\% de $200 \mathrm{~m}$ a $499 \mathrm{~m}$; e 6\% mais de $500 \mathrm{~m}$ de distância. Enquanto em Itacaré $14 \%$ das propriedades não possuíam curso d'água, $72 \%$ das propriedades apresentou cultivo com menos $29 \mathrm{~m}$ de faixa marginal. Já 7\% das propriedades a distância do cultivo foi de 100 a 199 m e 7\% mais de 500 m de distância.

No município de Maraú $17 \%$ não possuíam curso d’água em suas propriedades. Já $67 \%$ apresentavam faixas marginais a menos $29 \mathrm{~m}$ das áreas de cultivo. $8 \%$ com $30 \mathrm{~m}$ a $49 \mathrm{~m}$ e 8\%, com $100 \mathrm{~m}$ a $199 \mathrm{~m}$. Em Una 27\% das propriedades não possuíam faixas marginais. Das $73 \%$ restantes, $37 \%$ tinham menos de $29 \mathrm{~m}$ do local do cultivo; $9 \%$ de $50 \mathrm{~m}$ a $99 \mathrm{~m}$; $9 \%$ de $100 \mathrm{~m}$ a $199 \mathrm{~m}$; e $18 \%$ com mais de $500 \mathrm{~m}$ de distância.

Em Itajuípe $10 \%$ das propriedades não possuíam curso d'água. Das $90 \%$ restantes, $80 \%$ tinham menos de 29 m do local do cultivo; e $10 \%$ de 100 m a 199 m de distância. Em Uruçuca 25\% das propriedades não possuíam curso d’água. Das 75\% restantes, 50\% tinham menos de $29 \mathrm{~m}$ do local do cultivo; $13 \%$ de 50 m a 99 m; e $12 \%$ com mais de 500 m de distância.

Em Buerarema 33\% das propriedades não possuíam curso d’água. Das $67 \%$ restantes, todas tinham faixas com menos de $29 \mathrm{~m}$ do local do cultivo. Por fim, em Canavieiras $50 \%$ das propriedades não possuíam curso d’água. Das $50 \%$ restantes, $17 \%$ tinham menos de $29 \mathrm{~m}$ do local do cultivo; $17 \%$ de 200 m a 499 m; e 16\% mais de 500 m de distância.

As faixas marginais de qualquer curso d'água natural perene e intermitente, excluídos os efêmeros, são consideradas áreas de preservação permanente de acordo com o art. $4^{\circ}$ do Código Florestal (BRASIL, 2012). Contudo, em síntese, o parágrafo $6^{\circ}$ do art. $4^{\text {a }}$ (BRASIL, 2012) excetua que nos imóveis rurais com até 15 (quinze) módulos fiscais, é admitida nestas áreas de preservação permanente [...] "a prática da aquicultura e a infraestrutura física diretamente a ela associada.

Desta forma, ao menos $47 \%$ das propriedades sob análise não estão de acordo com este mandamento do Código Florestal. Isto porque não possuem a distância mínima de faixa marginal 
de curso d'água (trinta metros), mesmo se considerarmos que todas possuam curso d'água com a largura mínima prevista em lei (até dez metros). Nas áreas estudadas podem está sendo realizadas atividades antrópicas que estão descaracterizando os corpos d'água e afetando a disponibilidade dos recursos hídricos, o que também já foi constatado ao longo dos rios Jardim e Mutari na Bahia (Bandeira et al. 2019).

\section{Lagos, lagoas naturais e Reservatórios d'água artificiais}

Verificou-se que $60 \%$ das propriedades não possuem lagos e lagoas. Itabuna foi o único município onde todas as propriedades não possuíam. Na categoria lagos e lagoas a menos de 49 $\mathrm{m}$ de distância da área de cultivo enquadram-se $25 \%$ das propriedades, $1 \%$ com $50 \mathrm{~m}$ a $99 \mathrm{~m}$ de distância e 14\% com mais de 100 m de distância.

Em Ilhéus $87 \%$ das propriedades não possuíam lagos e lagoas. Das 13\% restantes, $10 \%$ tinham menos de 49 m do local do cultivo; e 3\% mais de $100 \mathrm{~m}$ de distância.

Itacaré apresentou $28 \%$ de propriedades que não possuíam lagos e lagoas. $43 \%$ com menos de $49 \mathrm{~m}$ do local do cultivo e $29 \%$ mais de $100 \mathrm{~m}$ de distância. No município de Maraú 33\% das propriedades não possuíam lagos e lagoas em suas propriedades. Os mesmos 33\% a apresentavam a menos de $49 \mathrm{~m}$ das áreas de cultivo e 34\% mais de $100 \mathrm{~m}$ de distância.

Em Una 64\% das propriedades não possuíam lagos e lagoas. Das 36\% restantes, $27 \%$ as tinham com menos de $49 \mathrm{~m}$ do local do cultivo, $9 \%$ de $50 \mathrm{~m}$ a $99 \mathrm{~m}$. Em Itajuípe $40 \%$ das propriedades não possuíam lagos e lagoas. Das $60 \%$ restantes, $30 \%$ as tinham a menos $49 \mathrm{~m}$ do local do cultivo, e 30\% a mais de $100 \mathrm{~m}$ de distância.

Em Uruçuca 63\% das propriedades não possuíam lagos e lagoas. Das 37\% restantes, todas tinham a menos de $49 \mathrm{~m}$ do local do cultivo. O mesmo ocorre em Buerarema, onde 83\% das propriedades não possuíam lagos e lagoas, e das $17 \%$ restantes, todas os tinham a menos de $49 \mathrm{~m}$ do local do cultivo. Por fim, em Canavieiras 33\% das propriedades não possuíam lagos e lagoas. Das $67 \%$ restantes, $33 \%$ as tinham a menos de $49 \mathrm{~m}$ do local do cultivo, e $34 \%$ a mais de $100 \mathrm{~m}$ de distância.

Desta forma, conforme art. $4^{\circ}$ do Código Florestal e o parágrafo $6^{\circ}$ do art. $4^{\mathrm{a}}$, mesmo se for considerado a faixa marginal mínima prevista em lei (cinquenta metros), ao menos $25 \%$ de todas as propriedades estão em desacordo com o quanto estabelecido pelo código florestal. O que vale dizer que das propriedades que possuem lagos ou lagoas, mais de 60\% estão em situação irregular (BRASIL, 2012).

No total geral $53 \%$ das propriedades não possuem reservatórios d’água artificiais. Na categoria reservatórios d'água artificiais a menos de $50 \mathrm{~m}$ de distância da área de cultivo encontraram-se $31 \%$

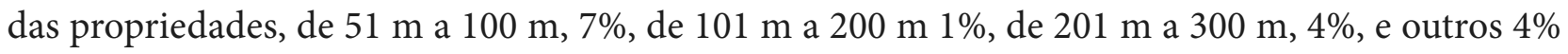
apresentam mais de $301 \mathrm{~m}$ de distância.

Em Ilhéus 65\% das propriedades não possuíam reservatórios d’água artificiais. Das 35\% restantes, $29 \%$ os tinham a menos de $50 \mathrm{~m}$ do local do cultivo, $3 \%$ de $51 \mathrm{~m}$ a $100 \mathrm{~m}$, e $3 \%$ de $201 \mathrm{~m}$ a $300 \mathrm{~m}$. Itacaré apresentou 50\% de propriedades que não possuíam reservatórios d’água artificiais, $29 \%$ das propriedades com menos de $50 \mathrm{~m}$ do local do cultivo, e $21 \%$ com mais de $301 \mathrm{~m}$ de distância. 
No município de Maraú 67\% não possuíam reservatórios d’água artificiais em suas propriedades. Já $17 \%$ apresentavam com menos de $50 \mathrm{~m}$ das áreas de cultivo; 8\% de $201 \mathrm{~m}$ a $300 \mathrm{~m}$, e com mais de $301 \mathrm{~m}$ também $8 \%$. Em Una, 9\% das propriedades não possuíam reservatórios d’água artificiais. Das $91 \%$ restantes, $64 \%$ os tinham a menos de $50 \mathrm{~m}$ do local do cultivo, $18 \%$ de $51 \mathrm{~m}$ a $100 \mathrm{~m}$, e $9 \%$ de $101 \mathrm{~m}$ a $200 \mathrm{~m}$.

Em Itajuípe 50\% das propriedades não possuíam reservatórios d’água artificiais. Das 50\% restantes, $20 \%$ os tinham a menos de $50 \mathrm{~m}$ do local do cultivo, $20 \%$ de $51 \mathrm{~m}$ a $100 \mathrm{~m}$, e $10 \%$ de 201 m a $300 \mathrm{~m}$. Em Uruçuca 63\% das propriedades não possuíam reservatórios d'água artificiais. Das $37 \%$ restantes, $25 \%$ os tinham a menos de $50 \mathrm{~m}$ do local do cultivo, e $12 \%$ de $201 \mathrm{~m}$ a $300 \mathrm{~m}$.

Em Buerarema, 50\% das propriedades não possuíam reservatórios d'água artificiais. Das 50\% restantes, todas os tinham a menos de $50 \mathrm{~m}$ do local do cultivo. Em Canavieiras $50 \%$ das propriedades não possuíam reservatórios d'água artificiais. Das $50 \%$ restantes, $33 \%$ tinham a menos de $50 \mathrm{~m}$ do local do cultivo, e $17 \%$ de $51 \mathrm{~m}$ a $100 \mathrm{~m}$ de distância. Por fim, em Itabuna $50 \%$ das propriedades não possuíam reservatórios d'água artificiais. Das $50 \%$ restantes, $25 \%$ os tinham a menos de $50 \mathrm{~m}$ do local do cultivo, e $25 \%$ de $51 \mathrm{~m}$ a $100 \mathrm{~m}$.

As áreas no entorno dos reservatórios d'água artificiais, decorrentes de barramento ou represamento de cursos d'águas naturais, são consideradas áreas de preservação permanente (BRASIL, 2012). De acordo com o parágrafo $1^{\circ}$ não será exigida APP quando esses reservatórios não decorrem de barramento ou represamento de cursos d'águas naturais. E mesmo nas acumulações naturais se a superfície for inferior a $1(\mathrm{um})$ hectare, fica dispensada a reserva da faixa de proteção, proibida nova supressão de áreas de vegetação nativa, salvo se autorizado pelo órgão ambiental competente.

O código não estabelece distância mínima para reservatórios artificiais. No entanto, os dados apresentados servem para a caracterização da região, e direcionamento de políticas.

Nascentes e os olhos d’água

Observou-se que 52\% das propriedades não possuem nascentes e olhos d'água. Itabuna foi o único município onde todas as propriedades da amostra não possuíam.

$\mathrm{Na}$ categoria de nascentes e olhos d'água a menos de $49 \mathrm{~m}$ de distância da área de cultivo encontraram-se 30\% das propriedades. E com mais de $50 \mathrm{~m}$ de distância, $18 \%$.

Em Ilhéus $64 \%$ das propriedades não possuíam nascentes e olhos d’água. Das 36\% restantes, $23 \%$ as tinham a menos de $49 \mathrm{~m}$ do local do cultivo, e $13 \%$ a mais de $50 \mathrm{~m}$ de distância. Em Itacaré $14 \%$ de propriedades não possuíam nascentes e olhos d'água. Com menos $49 \mathrm{~m}$ do local do cultivo, representou $50 \%$ das propriedades, e $36 \%$ a mais de $50 \mathrm{~m}$ de distância.

No município de Maraú 50\% não possuíam nascentes e olhos d’água em suas propriedades. Já $33 \%$ as apresentavam a menos de $49 \mathrm{~m}$ das áreas de cultivo, e $17 \%$ com mais de $50 \mathrm{~m}$. O município de Una apresentou-se fora da média, contendo a maior presença de nascentes e olhos d'água. Apenas $9 \%$ das propriedades não possuíam. Das $91 \%$ restantes, $64 \%$ as tinham a menos de $49 \mathrm{~m}$ do local do cultivo; e $27 \%$ a mais de $50 \mathrm{~m}$.

Em Itajuípe 70\% das propriedades não possuíam nascentes e olhos d’água. Das 30\% restantes, todas as tinham a menos de $49 \mathrm{~m}$ do local do cultivo. Já em Uruçuca 63\% das propriedades não 
possuíam nascentes e olhos d'água. Das 37\% restantes, todas as tinham a menos de $49 \mathrm{~m}$ do local do cultivo.

Buerarema apresentou $66 \%$ das propriedades sem nascentes e olhos d'água, $17 \%$ as possuíam a menos de $49 \mathrm{~m}$ do local do cultivo, e os mesmos $17 \%$ a mais de $50 \mathrm{~m}$. Por fim, em Canavieiras $67 \%$ das propriedades não possuíam nascentes e olhos d’água. Das 33\% restantes, todas as tinham a menos de $49 \mathrm{~m}$ do local do cultivo.

$\mathrm{O}$ art. 4 , inciso IV do Código Florestal (Brasil, 2012) estabelece que são áreas de preservação permanente as do "entorno das nascentes e dos olhos d'águas perenes, qualquer que seja sua situação topográfica, no raio mínimo de 50 (cinquenta) metros".

Desta forma, entre as $48 \%$ das propriedades que possuem nascentes e/ou olhos d'água, 30\% não cumprem o raio mínimo de cinquenta metros, e estão em desconformidade com a legislação. O que vale dizer que mais de $60 \%$ das propriedades que possuem nascentes na região, a possuem em situação de vulnerabilidade ambiental. Indicando que a cacauicultura não está preservando as nascentes e margens de cursos de água uma vez que essa atividade ocorre de forma integrada com a vegetação nativa, contrariando a afirmação de Leite (2018). Ou área destinadas a cacauicultura foram substituídas em larga escala por outras atividades (Aguiar e Pires, 2019) que por ter sido realizada de forma extensiva contribuiu para essa problemática (Bandeira et al. 2019).

Encostas ou partes destas com declividade superior a $45^{\circ}$

Observou-se que no total geral $72 \%$ das propriedades não possuem encostas ou partes destas com declividade superior a $45^{\circ}$. Canavieiras foi o único município onde todas as propriedades da amostra não possuíam. Na categoria de encostas ou partes destas com declividade superior a $45^{\circ}$ encontraram-se $27 \%$ das propriedades com menos de $49 \mathrm{~m}$ de distância da área de cultivo, e $1 \%$.com mais de $50 \mathrm{~m}$ de distância.

Em Ilhéus $77 \%$ das propriedades não possuíam encostas ou partes destas com declividade superior a $45^{\circ}$. Das $23 \%$ restantes, todas tinham menos de $49 \mathrm{~m}$ do local do cultivo. Já Itacaré apresentou $71 \%$ de propriedades que não possuíam encostas ou partes destas com declividade superior a $45^{\circ}$, as demais tinham menos $49 \mathrm{~m}$ do local do cultivo restantes.

No município de Maraú 67\% não possuíam encostas ou partes destas com declividade superior a $45^{\circ}$ em suas propriedades. Já 33\% apresentavam menos de $49 \mathrm{~m}$ das áreas de cultivo. É de se notar que o município de Una identificou-se maior presença de encostas ou partes destas com declividade superior a $45^{\circ}$. Apenas $45 \%$ das propriedades não possuíam, das 55\% restantes, todas as tinham menos de $49 \mathrm{~m}$ do local do cultivo.

Em Itajuípe $60 \%$ das propriedades não possuíam encostas ou partes destas com declividade superior a $45^{\circ}$. Das $40 \%$ restantes, todas as tinham a menos de $49 \mathrm{~m}$ do local do cultivo. Em Uruçuca $88 \%$ das propriedades não possuíam encostas ou partes destas com declividade superior a $45^{\circ}, 12 \%$ tinham menos de $49 \mathrm{~m}$ do local do cultivo.

Buerarema apresenta $67 \%$ das propriedades sem encostas ou partes destas com declividade superior a $45^{\circ}$, e das $33 \%$ restantes, todas possuíam a menos $49 \mathrm{~m}$ do local do cultivo. Por fim, em Itabuna $75 \%$ das propriedades não possuíam nascentes e olhos d'água, $25 \%$ estavam a mais de $50 \mathrm{~m}$ do local do cultivo, sendo o único município a enquadra-se nessa categoria. 
"As encostas ou partes destas com declividade superior a 45, equivalente a $100 \%$ (cem por cento) na linha de maior declive", são consideradas áreas de preservação permanente (Brasil, 2012). Contudo, de acordo com o parágrafo $5^{\circ}$ "é admitido, para a pequena propriedade ou posse rural familiar [...] o plantio de culturas temporárias e sazonais [...] desde que não implique supressão de novas áreas de vegetação nativa” (Brasil, 2012). Desta forma, 27\% das propriedades podem estar em desacordo com a lei.

Restingas, os manguezais, bordas dos tabuleiros ou chapadas no topo de morros, montes, montanhas e serras

Observou-se que 58\% das propriedades não possuem restingas, manguezais, bordas dos tabuleiros ou chapadas no topo de morros, montes, montanhas e serras. A menos de $100 \mathrm{~m}$ de distância da área de cultivo encontraram-se 37\% das propriedades, sendo que 1\% estavam com 101 m a 200 m, e $1 \%$ com 201 m a 300 m. E 3\% com mais de 301 m de distância.

Em Ilhéus $74 \%$ das propriedades não possuíam restingas, manguezais, bordas dos tabuleiros ou chapadas no topo de morros, montes, montanhas e serras, $26 \%$ estavam a menos de $100 \mathrm{~m}$ do local do cultivo. Itacaré apresentou $57 \%$ de propriedades que não possuíam, 36\% das propriedades com menos $100 \mathrm{~m}$ do local do cultivo, e 7\% mais de $301 \mathrm{~m}$ de distância.

No município de Maraú 75\% não possuíam restingas, manguezais, bordas dos tabuleiros ou chapadas no topo de morros, montes, montanhas e serras em suas propriedades. Já as $25 \%$ restantes estavam menos $100 \mathrm{~m}$ das áreas de cultivo. Em Una 27\% das propriedades não possuíam,64\% os tinham a menos de $100 \mathrm{~m}$ do local do cultivo, e $9 \%$ mais de $301 \mathrm{~m}$.

Em Itajuípe $40 \%$ das propriedades não possuíam restingas, manguezais, bordas dos tabuleiros ou chapadas no topo de morros, montes, montanhas e serras. Das $60 \%$ restantes, todas os tinham a menos de $100 \mathrm{~m}$ do local do cultivo. Uruçuca também apresenta apenas $25 \%$ das propriedades com áreas de restingas, manguezais, bordas dos tabuleiros ou chapadas no topo de morros, montes, montanhas e serras, $50 \%$ as tinham a menos de $100 \mathrm{~m}$ do local do cultivo, e $13 \%$ de $101 \mathrm{~m}$ a $200 \mathrm{~m}$ e $12 \%$ com mais de $301 \mathrm{~m}$.

Em Buerarema, 50\% das propriedades não possuíam restingas as demais as tinham a menos $100 \mathrm{~m}$ do local do cultivo. Em Canavieiras 50\% das propriedades não possuíam reservatórios d'água artificiais, 33\% tinham a menos $50 \mathrm{~m}$ do local do cultivo; e $17 \%$ de $51 \mathrm{~m}$ a $100 \mathrm{~m}$ de distância.

Por fim, em Itabuna $83 \%$ das propriedades não possuíam restingas, manguezais, bordas dos tabuleiros ou chapadas no topo de morros, montes, montanhas e serras. Das $17 \%$ todas as tinham a menos de $100 \mathrm{~m}$ do local do cultivo.

De acordo com os incisos VI a IX do artigo $4^{\circ}$ do Código Florestal (BRASIL, 2012) constata-se que $42 \%$ das propriedades possuem área de interesse ambiental, o que torna necessário um estudo caso a caso para aferir a regularidade dela.

Áreas em altitude superior a $1.800 \mathrm{~m}$ e Veredas

Em conformidade com o inciso X do art. 4 do Código Florestal (BRASIL, 2012), "as áreas em altitude superior a 1.800 (mil e oitocentos) metros, qualquer que seja a vegetação”, são áreas de 
preservação permanente. Contudo, observou-se com as entrevistas realizadas que nenhuma das propriedades pesquisadas possuía áreas em altitude superior a $1.800 \mathrm{~m}$.

Observou-se que do total geral $51 \%$ das propriedades não possuem veredas. Em $38 \%$ das propriedades cultivo encontraram-se a menos de $49 \mathrm{~m}$ de distância das veredas, e 11\% estavam com mais de $50 \mathrm{~m}$ de distância.

Em Ilhéus 55\% das propriedades não possuíam veredas, 39\% tinham a menos $49 \mathrm{~m}$ do local do cultivo e $6 \%$ a mais de $50 \mathrm{~m}$. Das propriedades de Itacaré, $43 \%$ não possuíam veredas 50 das propriedades restantes possuía menos de $49 \mathrm{~m}$ do local do cultivo e $7 \%$ mais de $50 \mathrm{~m}$ do local do cultivo.

No município de Maraú $67 \%$ não possuíam veredas em suas propriedades. Já $17 \%$ possuíam menos de 49 m e 16\% mais de $50 \mathrm{~m}$ do local do cultivo. Em Una 36\% das propriedades não possuíam veredas, $27 \%$ tinham menos de $49 \mathrm{~m}$ do local do cultivo e $37 \%$ a mais de $50 \mathrm{~m}$. Em Itajuípe $60 \%$ das propriedades não possuíam veredas e as restantes as tinham a menos de $49 \mathrm{~m}$ do local do cultivo.

Uruçuca apresenta $37 \%$ das propriedades sem veredas e as demais possuíam menos de $49 \mathrm{~m}$ do local do cultivo. Buerarema apresentou-se fora da média, contendo a menor presença de veredas, onde $83 \%$ das propriedades não possuíam. Das $17 \%$ restantes, todas tinham a menos de $49 \mathrm{~m}$ do local do cultivo. Por fim, em Itabuna 50\% das propriedades não possuíam veredas. Das 50\% restantes, $25 \%$ as tinham a mais de $49 \mathrm{~m}$ e 25 a mais de $50 \mathrm{~m}$ do local do cultivo.

De acordo com o Código Florestal, são áreas de preservação permanente "em veredas, a faixa marginal, em projeção horizontal, com largura mínima de 50 (cinquenta) metros, a partir do espaço permanentemente brejoso e encharcado" (BRASIL, 2012). Assim, ao menos 38\% das propriedades estão em confronto com a disposição legal. Dito de outra forma, entre as propriedades que possuem veredas, aproximadamente $78 \%$ estão em situação irregular.

Estudos realizados na área de legislação florestal e ambiental

Como se vê no Quadro 5, no total geral, em 83\% das propriedades não foi realizado estudos do plano da bacia hidrográfica. Ressalta-se que aqui também estão incluídas as propriedades que não possuem recursos hídricos. Em Itabuna, Maraú, Buerarema, Uruçuca e Canavieiras nenhuma propriedade possui estudos do plano da bacia hidrográfica. Já as propriedades nos municípios de Ilhéus, Itacaré, Una e Itajuípe possuíam 35\%, 18\% e 10\% e 7\% respectivamente.

Os estudos sobre zoneamento ecológico-econômico foram realizados apenas em $19 \%$ das propriedades. Ilhéus foi o município onde mais se realizou esse tipo de estudo, com $48 \%$ de suas propriedades. Por lado, todas as propriedades de Itabuna, Canavieiras, Buerarema, Uruçuca e Itacaré não realizaram (Quadro 5). 
Quadro 5 - Propriedades com estudos realizados na área de legislação florestal e ambiental no Sul da Bahia, em 2019, por município, em \%

\begin{tabular}{|c|c|c|c|c|c|c|c|c|c|c|c|c|c|c|c|c|c|c|c|c|}
\hline Estudos & \multicolumn{2}{|c|}{ Ilhéus } & \multicolumn{2}{|c|}{ Itacaré } & \multicolumn{2}{|c|}{ Maraú } & \multicolumn{2}{|c|}{ Una } & \multicolumn{2}{|c|}{ Itajuípe } & \multicolumn{2}{|c|}{ Uruçuca } & \multicolumn{2}{|c|}{ Buerarema } & \multicolumn{2}{|c|}{ Canavieiras } & \multicolumn{2}{|c|}{ Itabuna } & \multicolumn{2}{|c|}{ Geral } \\
\hline- & Sim & Não & Sim & Não & Sim & Não & Sim & Não & Sim & Não & Sim & Não & Sim & Não & Sim & Não & Sim & Não & Sim & Não \\
\hline Plano de bacia hidrográfica & 35 & 65 & 7 & 93 & 17 & 83 & 18 & 82 & 10 & 90 & 0 & 100 & 0 & 100 & 0 & 100 & 0 & 100 & 17 & 83 \\
\hline Zoneamento Ecológico-Econômico & 48 & 52 & 0 & 100 & 8 & 92 & 18 & 82 & 0 & 100 & 12 & 88 & 0 & 100 & 0 & 100 & 0 & 100 & 19 & 81 \\
\hline Formação de corredores ecológicos com outra & 35 & 65 & 0 & 100 & 8 & 92 & 18 & 82 & 10 & 90 & 0 & 100 & 0 & 100 & 0 & 100 & 0 & 100 & 15 & 85 \\
\hline $\begin{array}{l}\text { Reserva Legal, com Área de Preservação } \\
\text { Permanente, com Unidade de Conservação ou } \\
\text { com outra área legalmente protegida }\end{array}$ & 81 & 19 & 14 & 86 & 17 & 83 & 36 & 64 & 20 & 80 & 12 & 88 & 33 & 67 & 0 & 100 & 0 & 100 & 37 & 63 \\
\hline $\begin{array}{l}\text { Áreas de maior importância para a conservação } \\
\text { da biodiversidade }\end{array}$ & 55 & 45 & 7 & 93 & 0 & 100 & 18 & 82 & 10 & 90 & 12 & 100 & 0 & 100 & 0 & 100 & 0 & 100 & 22 & 78 \\
\hline Áreas de maior fragilidade ambiental & 55 & 45 & 0 & 100 & 0 & 100 & 18 & 82 & 20 & 80 & 0 & 100 & 0 & 100 & 0 & 100 & 25 & 75 & 22 & 78 \\
\hline
\end{tabular}

$\mathrm{N}=$ não, $\mathrm{S}=$ Sim, $\mathrm{P}=$ Parcialmente.

No total geral, $85 \%$ dos produtores afirmaram não ter realizado estudos sobre a formação de corredores ecológicos. Mais uma vez Ilhéus se destaca como o município que mais realizou esse tipo de estudo (35\% de suas propriedades). Todas as propriedades de Itabuna, Canavieiras, Buerarema, Uruçuca e Itacaré não realizaram (Quadro 5).

Neste tópico constatou-se um maior conhecimento desta temática em relação às anteriores, onde 37\% no total geral afirmaram já ter realizado em sua propriedade algum tipo de estudo sobre reserva legal, área de preservação permanente, unidade de conservação ou outra área legalmente protegida. Ilhéus mais uma vez se destaca com $81 \%$ das propriedades já realizando tal estudo. Apenas em Itabuna e Canavieiras todos os produtores afirmaram não ter realizado (Quadro 5).

No total geral, $78 \%$ dos produtores afirmaram não ter realizado estudos sobre áreas de maior importância para a conservação da biodiversidade. Ilhéus se destaca como o município que mais realizou esse tipo de estudo (55\% de suas propriedades). Todas as propriedades de Itabuna, Canavieiras, Buerarema, Uruçuca e Maraú não realizaram (Quadro 5).

Com resultado muito semelhante ao do questionamento do tópico anterior, no total geral, $78 \%$ dos produtores afirmaram não ter realizado estudos sobre áreas de maior fragilidade ambiental. Ilhéus se destaca como o município que mais realizou esse tipo de estudo (55\% de suas propriedades). Todas as propriedades de Canavieiras, Buerarema, Uruçuca, Maraú e Itacaré não realizaram (Quadro 5). 
Áreas de preservação permanente nas propriedades

No total geral, $40 \%$ das propriedades não possuem área de preservação permanente, segundo os produtores entrevistados. Já $24 \%$ afirmaram que de $1 \%$ a $10 \%$ de sua propriedade é composta por área de preservação permanente; $22 \%$ afirmam que $11 \%$ a $20 \%$ da propriedade tem de APP; $4 \%$ afirmam ter de $21 \%$ a $30 \%$ da propriedade de APP; $1 \%$, de $31 \%$ a $40 \%$; $4 \%$, de $41 \%$ a $50 \%$; $3 \%$, de $51 \%$ a $60 \%$; $1 \%$, de 61 a 70\%; e $1 \%$ mais de $70 \%$ (Quadro 6). Essa falta de ocorrência de APP contraria Leite (2018), ao afirmar que, normalmente, em áreas com cacau cultivado há ocorrência de floresta preservada, uma vez que um grande volume de cacau é obtido de sistemas não permitem a derrubada da vegetação nativa.

Quadro 6 - Percentual de áreas de preservação permanente nas propriedades de cacau do Sul da Bahia, em 2019, por município

\begin{tabular}{|c|c|c|c|c|c|c|c|c|c|}
\hline Municípios & $\begin{array}{c}\text { Não } \\
\text { possui }\end{array}$ & $\begin{array}{c}\text { De 1 a } \\
10\end{array}$ & $\begin{array}{c}\text { De 11 a } \\
20\end{array}$ & $\begin{array}{c}\text { De 21 a } \\
30\end{array}$ & $\begin{array}{c}\text { De 31 a } \\
40\end{array}$ & $\begin{array}{c}\text { De 41 a } \\
50\end{array}$ & $\begin{array}{c}\text { De 51 a } \\
60\end{array}$ & $\begin{array}{c}\text { De 61 a } \\
70\end{array}$ & $\begin{array}{c}\text { Mais de } \\
71\end{array}$ \\
\hline Ilhéus & 40 & 13 & 32 & 6 & 0 & 3 & 6 & 0 & 0 \\
\hline Itacaré & 29 & 29 & 14 & 7 & 0 & 14 & 0 & 7 & 0 \\
\hline Maraú & 50 & 33 & 17 & 0 & 0 & 0 & 0 & 0 & 0 \\
\hline Una & 28 & 36 & 18 & 0 & 0 & 0 & 9 & 0 & 9 \\
\hline Itajuípe & 50 & 30 & 10 & 10 & 0 & 0 & 0 & 0 & 0 \\
\hline Uruçuca & 25 & 37 & 12 & 0 & 13 & 13 & 0 & 0 & 0 \\
\hline Buerarema & 66 & 17 & 17 & 0 & 0 & 0 & 0 & 0 & 0 \\
\hline Canavieiras & 67 & 0 & 33 & 0 & 0 & 0 & 0 & 0 & 0 \\
\hline Itabuna & 50 & 25 & 25 & 0 & 0 & 0 & 0 & 0 & 0 \\
\hline Geral & 40 & 24 & 22 & 4 & 1 & 4 & 3 & 1 & 1 \\
\hline
\end{tabular}

Segundo Piasentin et al. (2014) muitos cacauais foram historicamente implantados e a ainda permanecem nas áreas férteis dos vales ao longo dos rios, que pela legislação brasileira deveriam compor as áreas de preservação permanente (APP) com vegetação nativa, assim o corte da mata ciliar gera conflito entre ambientalistas e produtores de cacau. Contudo, a presença de agroflorestas foi incluída nas APPs, apenas no caso de pequenas propriedades familiares, após as alterações feitas no Código Florestal. Aguiar e Pires (2019) ainda ressaltam que as maiores extensões de Mata Atlântica preservadas estão associados ao plantio de cacau sob o sistema Cabruca.

Em Ilhéus, $40 \%$ das propriedades não têm áreas de preservação permanente. A maior concentração de APP está nas propriedades que a possuem entre $11 \%$ a $20 \%$ da propriedade (32\%). Itacaré apresenta os mesmos $29 \%$ entre os que não possuem APP e os que possuem numa proporção que compreende $1 \%$ a $10 \%$ da propriedade (Quadro 6).

Maraú, Itajuípe e Itabuna não possuem áreas de APP em 50\% de suas propriedades. Todos esses municípios apresentam maior concentração de APP na proporção em que ela representa de 1\% a $10 \%$ da propriedade $(33 \%, 30 \%$ e $25 \%$ respectivamente) (Quadro 6). 
Em Uruçuca apresentou-se fora da média, onde apenas $25 \%$ das propriedades não tem área de preservação permanente. Das que possuem, a maior porção está entre as que ocupam 1\% a 10\% da propriedade. Também fora da média por motivo contrário estão os municípios de Buerarema e Canavieiras, que apresentaram o maior número de propriedades sem áreas de preservação permanente (66\% e $67 \%$ respectivamente). Buerarema possui valor igual (17\%) de propriedades com APP que representam de $1 \%$ a $10 \%$ e $11 \%$ a $20 \%$ da propriedade. Já, o município de Canavieiras só possui áreas de APP que representam de 11\% a 20\% da propriedade (33\%) (Quadro 6).

Áreas de reserva legal nas propriedades

No tocante às áreas de reserva legal observou-se que 61\% das propriedades descumprem a previsão legal, que a princípio exige que ao menos $20 \%$ de sua área seja de reserva legal. Das 39\% que cumprem a previsão, a reserva legal representa em sua maioria (16\%) de $41 \%$ a $50 \%$ da propriedade (Quadro 7). Esse descumprimento se deve a pressão que os recursos naturais vem sofrendo, desde a última crise do cacau, que promoveu a substituição do cacau por áreas de pasto para a pecuária bovina, por outras culturas agrícolas e outras atividades (Aguiar e Pires, 2019).

Quadro 7 - Propriedade de cacau com áreas de reserva legal, do Sul da Bahia, em 2019, por município, em $\%$

\begin{tabular}{|c|c|c|c|c|c|c|c|c|c|}
\hline Municípios & $\begin{array}{c}\text { Não } \\
\text { possui }\end{array}$ & $\begin{array}{c}\text { De } 1 \mathrm{a} \\
10\end{array}$ & $\begin{array}{c}\text { De } 11 \mathrm{a} \\
20\end{array}$ & $\begin{array}{c}\text { De } 21 \mathrm{a} \\
30\end{array}$ & $\begin{array}{c}\text { De 31 a } \\
40\end{array}$ & $\begin{array}{c}\text { De } 41 \text { a } \\
50\end{array}$ & $\begin{array}{c}\text { De } 51 \text { a } \\
60\end{array}$ & $\begin{array}{c}\text { De } 61 \text { a } \\
70\end{array}$ & $\begin{array}{c}\text { Mais de } \\
71\end{array}$ \\
\hline Ilhéus & 33 & 10 & 29 & 13 & 0 & 6 & 6 & 3 & 0 \\
\hline Itacaré & 14 & 30 & 0 & 0 & 7 & 21 & 14 & 14 & 0 \\
\hline Maraú & 34 & 33 & 8 & 0 & 0 & 25 & 0 & 0 & 0 \\
\hline Una & 28 & 27 & 9 & 0 & 0 & 9 & 9 & 0 & 18 \\
\hline Itajuípe & 40 & 30 & 20 & 10 & 0 & 0 & 0 & 0 & 0 \\
\hline Uruçuca & 25 & 0 & 13 & 12 & 0 & 50 & 0 & 0 & 0 \\
\hline Buerarema & 17 & 17 & 0 & 17 & 0 & 32 & 0 & 17 & 0 \\
\hline Canavieiras & 17 & 16 & 0 & 50 & 0 & 0 & 0 & 17 & 0 \\
\hline Itabuna & 0 & 0 & 50 & 0 & 25 & 25 & 0 & 0 & 0 \\
\hline Geral & 26 & 19 & 16 & 10 & 2 & 16 & 4 & 5 & 2 \\
\hline
\end{tabular}

Em Ilhéus, 33\% das propriedades não têm áreas de reserva legal. A maior concentração de reservas legais estava nas propriedades que a possuem entre $11 \%$ a $20 \%$ da propriedade (29\%). Itacaré apresentou $14 \%$ de propriedade entre os que não possuem áreas de reserva legal, e $30 \%$ a possuem numa proporção que compreende $1 \%$ a $10 \%$ da propriedade (Quadro 7).

Itajuípe se destaca como o município que menos apresentou áreas de reserva legal (40\%). Itabuna se destaca pelo fator contrário, pois todas as propriedades possuem tais áreas. Una foi o único município a apresentar grandes áreas de reversa legal, que ocupam mais de $71 \%$ da propriedade (18\%) (Quadro 7). 
As propriedades que aparentemente estão descumprindo a cota mínima de reserva legal podem ser receptores dos benefícios concedidos pelo Código Florestal às pequenas propriedades rurais. Para isso, deverão ter realizado o CAR/CEFIR, ter cumprido o quanto disposto no termo de compromisso, e apenas nos casos em que a supressão da vegetação nativa ocorreu antes 22 de julho de 2008. Contudo, essas informações só seriam possíveis numa análise individualizada.

\section{Conclusão}

No tocante à legislação florestal e ambiental, a maioria dos produtores concordam sem ressalva com o Código Florestal e a legislação ambiental e os consideram de alta importância, assim como as áreas de preservação permanente e de reserva legal.

A maioria dos entrevistados afirmaram conhecer totalmente a legislação florestal brasileira. Contudo, algumas propriedades não atendem totalmente ao especificado na legislação ambiental, principalmente com relação ao plano de bacia ou de gestão de recursos hídricos, licenciamento pelo órgão ambiental e Inscrição no Cadastro Ambiental Rural - CAR ou CEFIR.

A maior parte das propriedades que possuem lagos ou lagoas está em situação irregular nesse quesito, o mesmo foi observado para as propriedades que possuem nascentes na região, encostas ou partes destas com declividade superior a $45^{\circ}$, veredas e áreas de reserva legal.

Sobre a fiscalização das propriedades, a maioria não é fiscalizada pelo órgão ambiental periodicamente, dificultando o cumprimento da legislação e o desenvolvimento sustentável. Assim, muitas propriedades não estão de acordo com esta norma do Código Florestal.

Participação dos autores: STR - coleta e tabulação dos dados, revisão de literatura, redação do trabalho; NSS orientação para desenvolvimento de todo o trabalho, tabulação e análise dos dados; LJSR - coleta de dados, discussão dos resultados.

Aprovação ética ou licenças de pesquisa: Aprovado pelo Comitê de Ética da Universidade Estadual de Santa Cruz, sob parecer 3.269.201, em 16 de Abril de 2019.

Disponibilidade dos dados: Os dados não estão disponíveis em nenhuma base ou repositórios.

Fomento: pesquisas financiada pela Universidade Estadual de Santa Cruz e pelo Centro de Inteligência do Cacau.

Conflito de Interesses: os autores declararam não haver conflito de interesses.

\section{Referências}

Almeida GW. 2012. Gênese da economia cacaueira e da firma. Revista Brasileira de Administração Política, 5(1):50-66.

Aguiar PCB, Pires, M.M. 2019. A região cacaueira do sul do estado da Bahia (Brasil): crise e transformação. Cuadernos de Geografía: Revista Colombiana de Geografía, 28(1):192-208.

Bandeira MSF, Nascimento LD, Santos RF, Tessmann C, Silva AG, Bandeira MLSF. 2019. Impactos ambientais de rios com nascentes em unidade de conservação: avaliação preliminar dos rios Mutari e Jardim, Santa Cruz Cabrália, Bahia. R. gest. sust. ambient., 8(3):389-417.

Brasil. Constituição (1988). Constituição da República Federativa do Brasil. Brasília, DF: Senado Federal: Centro Gráfico, 1988. 
Brasil. Lei $n^{\circ}$ 12.651, de 25 de maio de 2012. Dispõe sobre a proteção da vegetação nativa; altera as Leis $n^{\circ} 6.938$, de 31 de agosto de 1981, 9.393, de 19 de dezembro de 1996, e 11.428, de 22 de dezembro de 2006; revoga as Leis $\mathrm{n}^{\circ} 4.771$, de 15 de setembro de 1965, e 7.754, de 14 de abril de 1989, e a Medida Provisória nº 2.166-67, de 24 de agosto de 2001; e dá outras providências. Diário Oficial [da] República Federativa do Brasil, Brasília, 25 mai. 2012. Disponível em: <http:// www.planalto.gov.br/ccivil_03/_ato2011 2014/2012/lei/l12651.htm>Acesso em: jul. 2018.

Chambouleyron, R. 2014.O plantio do cacau na Amazônia colonial (séculos XVII e XVIII). In: Christillino CL, Brandao TMP. Nas bordas da plantation: agricultura e pecuária no Brasil Colônia e Império. 1. ed. Recife: Editora da UFPE, p. 111-153.

Gil AC. 2002. Como elaborar projetos de pesquisa. São Paulo: Atlas, 42 p.

Jardim MH, Bursztyn MA. 2015. Pagamento por serviços ambientais na gestão de recursos hídricos: o caso de Extrema (MG). Engenharia Sanitaria e Ambiental, 20(3):353-360.

Instituto Brasileiro de Geografia e Estatística - IBGE. Censo Agropecuário - 2017. Disponível em: https://censos.ibge. gov.br/agro/2017. Acesso em: 08/12/2020.

Klein L, Fragalli AC, Panhoca L, Garcias PL, 2015. Mudanças no Código Florestal: Uma análise institucional da percepção de produtores agrícolas de um município do Paraná. Revista de Gestão Ambiental e Sustentabilidade - GeAS, 4(1):124138.

Leite SA, Castellani MA, Ribeiro AEL, Moreira AA, Aguiar WMM. 2016. Perfil dos fruticultores e diagnóstico do uso de agrotóxicos no polo de fruticultura de livramento de nossa senhora, Bahia. Extensão Rural, DEAER - CCR - UFSM, 23(2):112-125.

Leite LRC. 2018. Estudo de Competitividade do Cacau e Chocolate no Brasil: Desafios na Produção e Comércio Global. Brasília: MDIC, 128 p.

Oliveira AS, Castellani MA, Nascimento AS, Moreira AA. 2016. Perfil do sistema de produção de pinha nos polos de fruticultura da Bahia, com ênfase nos aspectos fitossanitários da cultura. Extensão Rural, DEAER - CCR - UFSM, 23(2):95-111.

Piasentin FB, Saito CH, Sambuichi RHR. 2014. Preferências locais quanto às árvores do sistema cacau-cabruca no sudeste da Bahia. Ambiente \& Sociedade, 17(3): 55-78.

Polízio Júnior V. 2016. Novo Código Florestal Comentado. São Paulo: Rideel, 627 p.

Rocha LB. 2008. A região cacaueira da Bahia - dos coronéis à vassoura-de-bruxa: saga, percepção, representação. Ilhéus: Editus, $254 \mathrm{p}$.

Silva NL. 2012. Diretrizes para a construção de uma legislação florestal na visão de produtores (as) rurais: bacia hidrográfica do Mina, Matias Barbosa - MG. Dissertação (Mestrado em Ecologia Aplicada a Conservação e Manejo de Recursos Naturais), Universidade Federal de Juiz de Fora, 67 p.

Sambuichi, RHR. 2006. Estrutura e dinâmica do componente arbóreo em área de cabruca na região cacaueira do sul da Bahia, Brasil. Acta Botanica Brasilica, 20(4): 943-954.

Sant 'Ana, C. S; PEREIRA, I. O.; FERREIRA, A. C.R.; SILVA, A. V. Influência do período de colheita na qualidade do cacau da Indicação Geográfica Sul da Bahia. Brazilian Journal of Development. 6(2), p. 8295-8306, 2020.

Segundo GSA, Goulart LA, Silva Junior, MF, Uetanabaro APT. 2014. O cacau da região sul da Bahia e a perspectiva histórica de uma indicação geográfica. Cad. Prospec., 7(4): 632-639.

Sirvinskas LP. 2018. Manual de direito ambiental. São Paulo: Editora Saraiva, 1016 p. 
Tourinho LAM. 2005. O Código Florestal na pequena propriedade rural: um estudo de caso em três propriedades na microbacia do rio Miringüava. Dissertação (Mestrado em Geografia), Universidade Federal do Paraná, 99 p.

Viana EC. 2004. Análise jurídico - dogmática da legislação florestal e do direito ao ambiente frente à função social da propriedade. Tese (Doutorado em Ciência Florestal), Universidade Federal de Viçosa, 169 p. 